\title{
10
}

\section{The empty coast: Conditions for human occupation in southeast Australia during the late Pleistocene}

\author{
Sandra Bowdler \\ Archaeology M405, School of Social and Cultural Studies, University of Western Australia, Perth, Australia \\ sandra.bowdler@uwa.edu.au
}

\section{Introduction}

Archaeology, particularly Australian archaeology, and particularly the archaeology of the pre-European Australian past, is significantly dependent on other disciplines. One of our main interests has been understanding the relationship of Aboriginal people to their environments, and to this end, we have collaborated, with differing degrees of closeness, with geomorphologists, palaeontologists and, of course, palynologists. Geoff Hope is an outstanding example of the last, and has contributed greatly to our knowledge of past environments and their significance for human occupation. I have personally been privileged to work with Geoff, and his contribution to my research, and to the wider questions raised by that research, has been inestimable.

\section{Geoff Hope and the Pleistocene occupation of Tasmania}

Some 40 years ago, Rhys Jones published a paper entitled The geographical background to the arrival of man in Australia and Tasmania (Jones 1968). This was in itself an important example of the need for input from other disciplines to our understanding of the human past and its environmental context. In that paper, Jones was concerned to explain the (then) lack of evidence for humans in Tasmania during the Pleistocene. The oldest human occupation sites known at the time were all well within the Holocene, with the oldest being Rocky Cape South, dated to around 8000 BP. The lowest levels of Rocky Cape South contained evidence for a well-developed coastal economy, consisting of dense shell midden material containing marine shell and fish remains, as well as land mammals and birds. Because of its steep offshore profile, $8000 \mathrm{BP}$ was close to the time when the sea reached its present position at Rocky Cape. Jones argued that the inhabitants of the cave had probably been living on the Pleistocene coast at times of lower sea level, and arrived at Rocky Cape with the rising sea. 
This left the problem of where people were during the Pleistocene, and why they were not occupying what were at the time inland parts of Tasmania. Jones (1968:200) argued that, given the evidence for a firmly established coastal economy and lifestyle, Tasmanian Aborigines during the Pleistocene were tightly constrained to the coast by dense, cool, temperate rainforest that, based on the evidence of the immediate pre-European past, was not conducive to human occupation. Those parts of Tasmania which were not clothed with rainforest were covered with glaciers and permafrost: 'most of Tasmania was inhospitable and probably uninhabited' (Jones 1968:200).

My doctoral research on Hunter Island, northwest Tasmania, showed human occupation dating to c. 22,000 years ago (Bowdler 1984). This in itself did nothing to dispel Jones's theory. Hunter Island during the Pleistocene was a small hill on the Bassian Plain, probably about $100 \mathrm{~km}$ from the coast. Human occupation in Cave Bay Cave, on the east side of the island, was intermittent: between 22,000 and 18,000 BP people lit fires, hunted land mammals and left behind stone and bone artefacts. A single hearth represented a visitation about 15,000 years ago, but more intensive occupation did not recur until c. 7000 years ago, when the sea reached its present level. The evidence for that period resembles that from the basal layers of Rocky Cape South, consisting of shell midden material containing some fish bones, sea-bird bones and small mammals.

What was crucial for a new interpretation of Pleistocene human occupation of Tasmania was the pollen evidence which recurred throughout the Cave Bay Cave sediments, and which was the subject of study by Geoff Hope (Hope 1978). Hope was able to show that, far from being covered by dense rainforest, the environment of northwest Tasmania, at least, including the exposed Bassian Plain, was an expanse of sweeping grassland. This was supported by the analysis of faunal remains from Cave Bay Cave, but the pollen evidence was the important factor, since bolstered by other studies.

If there was no environmental barrier, why were people apparently restricted to the Pleistocene coast? In the first instance, I argued (Bowdler 1977) that the Aboriginal colonists of Australia were coastally adapted, and rarely made forays away from the immediate coast. Further evidence, however, showed that Pleistocene Tasmanians were not, in fact, so restricted. Starting with Kutikina Cave on the Franklin River in the early 1980s, the discovery of inland sites in southwest Tasmania opened a new window on Pleistocene Tasmania (e.g. Jones 1995).

In the historic period, southwest Tasmania comprised dense, cool, temperate rainforest with a narrow high-energy coastal fringe. All the ethnohistorical records, and the archaeological evidence such as it was to that time, suggested that while dense shell middens showed the coastal strip was well-utilised by Aboriginal people, the rainforest interior was practically unoccupied. It had been pointed out by Jones (1968) that Aborigines had used fire to convert some of the edges of the rainforest to more productive sedgeland, and also to maintain tracks through it, but essentially the rainforest interior was inimical to human occupation.

Once it was realised, however, that the rainforest had not expanded during the Pleistocene, but on the contrary, had shrunk to small pockets, it was evident that it did not form a barrier to human occupation or at least utilisation of the areas it had covered in the recent past. A number of sites dating from about 13,000 to 35,000 years ago show exploitation of cave sites on river systems in southern Tasmania up to $100 \mathrm{~km}$ from the coast, with a concentration on the exploitation of wallabies (Allen 1996).

Further evidence of Pleistocene occupation of Tasmania has been found in the Furneaux Islands, on what would have been the exposed Bassian Plain. Mannalargenna Cave on Prime Seal Island, off the west coast of Flinders Island, was occupied from c. 22,000 to 8000 BP. Human remains were found in Cliff Cave on the west side of King Island, dated to around 14,000 years ago. Other Bass Strait island sites were occupied mostly between about 10,000 
and 4000 years ago, and were, apart from the Hunter Group, not occupied or visited by humans in the ethnographic present (Sim 1994).

It is still the case that no Pleistocene sites are known from the north, northeast or southeast coasts of Tasmania. Apart from the sites located on the river systems of the southern forest region (see Allen 1996), there are no interior Pleistocene sites. The site of Warragarra, some $80 \mathrm{~km}$ from the sea in northern Tasmania, was expected to contain such deposits, but its basal occupation levels are dated to c. 11,000 BP (Allen and Porch 1996).

Eastern Tasmania is thus devoid of evidence for Pleistocene occupation. When the sea reached its present level, however, there is evidence that people began exploiting littoral resources, just as in the northwest (contra Cane 2001:150). In northwest Tasmania, as we have seen, Rocky Cape South and Cave Bay Cave both showed evidence of coastal economies dating to 8000-7000 BP and in the southeast, the sites at Carlton Bluff and Apollo Bay on Bruny Island demonstrate something similar (Dunnett 1993). The main difference is that in the northwest, people were exploiting a high-energy rocky shoreline, and in the southeast, the sites are in sheltered embayments and contain shellfish species from low-energy, estuarine habitats. For both situations, however, the question remains: where were these people during the earlier time of lower sea level? It seems unlikely that this lack of evidence is due to differential preservation, in that rock shelters capable of preserving Pleistocene evidence occur in these areas, particularly the Rocky Cape caves and others in that area. Were people for some reason tethered to the Pleistocene coastline or did they become archaeologically instantaneous coastal exploiters just as the sea reached its present level? Since the latter seems unlikely (just as Jones argued in 1968), the former is a better hypothesis, but at this stage, it is difficult to establish whether it is culturally or environmentally determined. It might also be wondered whether the wallaby hunters of the southern Tasmanian forests were striking inland from coastal bases, or represent a quite different adaptation from the coastal dwellers of the northwest and southeast. Recent research by Pike-Tay et al. (2008) on dental growth-increment analysis of wallaby teeth from relevant sites seems to support year-round occupation of the interior region, which does suggest a different non-coastal adaptation.

\section{Eastern mainland Australia during the Pleistocene}

Moving north to what is now the Australian mainland, we find even less evidence for Pleistocene occupation on the eastern Australian coastal strip, which is here considered to extend from the shoreline to the bottom of the eastern mountains, and from Mornington Peninsula to Cooktown. Within this extensive area, after many years of concentrated archaeological attention, only three generally accepted sites of Pleistocene age are known. They are Burrill Lake, Bass Point and Wallen Wallen Creek: all are problematic with respect to their dating (Bowdler 1999). The last is a sandy site with dating (c. 21,000 BP) based on dispersed charcoal; it has not been fully reported (Neal and Stock 1986; Ulm et al. 1995). The lowest layer of the Bass Point site is also a sandy deposit, for which the dating (c. 17,000 BP) is also based on scattered charcoal which could have blown into the site from anywhere (Bowdler 1970, 1976). The dating of the lowest level of the Burrill Lake rock-shelter site might equally be called into question. It consists of a 'clay wedge', which is thought to have been deposited with great rapidity, possibly from local soil instability due to Aboriginal firing (Hughes 1981). This idea is supported by the two dates for this layer, one from the top $(20,801 \pm 810 \mathrm{BP})$ and one from the bottom $(20,760 \pm 800 \mathrm{BP})$, which are statistically identical. The source of the dates was dispersed charcoal (Lampert 1971). It can be argued that the material dated was charcoal swept into the rock shelter with clay, entirely unconnected with the human occupation. If we 
dismiss these three dated sites, we are left with little convincing evidence of human occupation during the Pleistocene on the eastern Australian coastal strip.

A small number of sites in the Sydney region are said to be of Pleistocene age, but all consist of artefacts in open sand contexts, and none have been reported in detail. Only one appears to have a published date. A sand body on the Paramatta River has produced a date of $30,735 \pm 407$ BP (Wk-17435) (McDonald 2008:36). Any information on the dating material, collection method, archaeological association and so on for this site, and the others, would seem to be buried in unpublished reports. Until such time as these dates can be validated by published details, I choose to discount them.

The oldest well-established dates on the coastal strip generally date to the mid Holocene. Right on the coast, there are some dates for human occupation, which, as in Tasmania, coincide approximately with the sea reaching its present level. Examples are Nara Inlet 1, on Hook Island in the Whitsundays on the Queensland coast (c. 8000 BP, Barker 2004), Border Island near Proserpine also on the Queensland coast (c. 6500 BP, Barker 2004), Swansea Inlet near Newcastle (c. 7900 BP, Gillespie and Temple 1977; Dyall 1982), Curracurrang near Sydney (c. 7500 BP, Megaw 1968), Currarong at Jervis Bay (c. 6000 BP, Lampert 1971), and Wilsons Promontory (c. 6600 BP, Coutts 1967). The dating of all of these is not absolutely secure, it must be said, but the dates from Nara Inlet, Curracurrang and Currarong are well-published and convincing. Only Nara Inlet seems to be obviously associated with evidence of a coastal economy, such as we find in Tasmania and parts of the southern Australian coastline west of Wilson's Promontory (Cane 2001). This phenomenon of an apparently late development of coastal economies has been considered by Beaton (1985), as well as Cane (2001). From the wider perspective with which I am concerned here, the question is, are these sites evidence of people pushed back from narrowly inhabited Pleistocene shoreline by post-glacial sea-level rise, or have the inhabitants come from elsewhere?

When we look at more interior sites, which are still on the coastal strip but not right on the coast, we find a plethora of sites dating to between 12,000 and 8000 BP (e.g. Boot 1993, 1994; Stockton 1993; Attenbrow 2004). Moving into the more elevated areas, evidence for human occupation is considerably older. In the Blue Mountains, convincing dates for human occupation are of the order of 12,000-14,000 years (Stockton 1993). A date of c. 22,000 BP is less convincing in view of its depositional situation and its being associated only with a single stone flake (Bowdler 1981). For similar reasons, a date of c. 21,000 BP for human occupation at the site of Birrigai in the ACT is not as credible as a somewhat younger one of c. 16,000 BP (Flood et al. 1987). Also somewhat problematic is a site in the rugged areas near the Hunter Valley north of Sydney, located on Fal Brook. Charcoal associated with stone artefacts in an open soil matrix produced three dates, one of c. 35,000 BP, one of $>20,000 \mathrm{BP}$ and one of c. $13,000 \mathrm{BP}$. The charcoal associated with the second date is said to have come from a hearth (Attenbrow 2004:350). No published information is available about the stratigraphy and archaeological associations of these dates.

In more northerly parts of the eastern highlands, in south-central Queensland, human occupation has been dated to c. 19,000 at the Kenniff Cave site (Mulvaney and Joyce 1965). Further north again, we have one of the oldest sites in Australia, Ngarrabullgan Cave on Mount Mulligan in the interior of Cape York, some $100 \mathrm{~km}$ from the coast and dated to about 40,000 BP (David et al. 1997). The nearby site of Nonda Rock has occupation from about the same age (David et al. 2007). Further west of the Great Dividing Range, the semiarid region of the Willandra Lakes has produced evidence for human occupation of similar antiquity (e.g. Bowler et al. 2003). These sites have all been published in considerable detail, and the associations are clear.

This takes us back to the observation made by Jones in 1968, before Burrill Lake had been dated, that perhaps there was a west-to-east gradient in the prehistoric colonisation of 
Australia. It is, of course, possible that this pattern is completely illusory, due to the vagaries of research, or the result of differential site preservation over time, with old sites being destroyed by natural processes (cf. Rowland 1996:195). This is not, however, the case along the western and southern margins of the continent, where Pleistocene sites occur not far from the coast, many showing evidence that the inhabitants either visited the coast themselves, or had contact with people who lived there (Bowdler 1999; Morse 1999; O'Connor 1999; Cane 2001). It might also be pointed out that archaeological investigation along the eastern coastal strip has been highly intensive, particularly compared with the southern coastline of Australia.

If we accept that the eastern coast of Australia was indeed empty during the Pleistocene, and this is not an artefact of research or erosion, how might we account for it? One line of inquiry might be to consider environmental factors which might have influenced human occupation during the Pleistocene.

\section{Environmental considerations}

Callaghan (1980) pointed out nearly 30 years ago that the east coast of Australia might not have been all that desirable a place to live during the Pleistocene. What we now see as a wellwatered, fertile area abounding in resources for human occupation was very different during times of lowered sea level. Lowered temperatures and increased aridity due particularly to decreased effective precipitation may have contributed to a more difficult environment for human occupation. Fluctuating sea levels may also have led to a less productive shoreline (see also Lampert and Hughes 1974).

It has often been suggested (e.g. Morse 1999) that where the continental shelf is at its narrowest, we are most likely to find Pleistocene occupation sites if people are coastally oriented, economically and/or culturally, and this does appear to be the case in Western Australia. On the east coast of Australia, however, as Callaghan (1980) pointed out, the continental shelf is generally equally narrow, but this narrowness at times of lower sea level would have created a most unproductive shoreline for human exploitation. In the central-south coast area of New South Wales, the mid-to-late Holocene shoreline was a productive combination of rocky headlands ringed with rock platforms and short sandy beaches, interspersed with river and lagoonal estuarine situations. At times of lower sea level, it may have consisted of a far less productive stretch of long sandy beaches, fewer rocky expanses, and smaller estuaries (Attenbrow 2004:212). Further north, lowered sea level would have left the coastal strip similarly more challenging for human exploitation. Rather than a gentle tropical shore protected by the Great Barrier Reef, the Pleistocene coastline would have consisted of cliffed limestone ridges, rising $100 \mathrm{~m}$ or more above sea level, following the outer edge of the present reef (Border 1999:130).

If the coasts were not as benign as in more recent times, we may wonder why there is not more evidence for occupation of the hinterland earlier than the terminal Pleistocene. There is little direct data for the nature of the eastern Australian strip during the Pleistocene, with most pollen studies being restricted to the Holocene (e.g. Dodson and Thom 1992). Research by Hesse et al. (2004) indicates extreme conditions during the Last Glacial Maximum (LGM), with dune formation taking place on the Blue Mountains, suggesting high aridity and sparse vegetation cover. Dune formation was also active on the coast itself; at Kurnell, strong westerlies blew up dunes from the exposed bed of Botany Bay (Lees 2006). In northeast Queensland, evidence from Lynch Crater on the Atherton Tableland suggests decreased effective precipitation during this period (Kershaw 1995). Kershaw (1995), extrapolating mainly from research in Tasmania (including that of Hope) and western Victoria, suggested that much of southeastern Australia was covered with a fairly homogeneous Poaceae-Asteraceae steppe during the LGM, but there is no direct evidence that this applied to the eastern coastal strip. 
McGowan et al. (2008) discuss atmospheric dust loads during the Quaternary, based on research on Stradbroke Island off southeast Queensland, and conclude that increased dust load in eastern Australia during the LGM was due to severe and prolonged drought. They calculate that the total aeolian sedimentation flux during the LGM reached a maximum of more than 80 times that calculated for the early Holocene (McGowan et al. 2008:177). They infer more frequent dry southwesterly winds, less frequent maritime easterly winds, reduced rainfall, lower temperatures, increased continentality as a result of lower sea levels $(-120 \mathrm{~m})$, leading to a marked change in the floristic composition of local vegetation, with thinner vegetation cover and an increased percentage of bare ground. While it might be argued that the period of the LGM was but a passing and relatively short-term (at least in archaeological terms) event, further research on Stradbroke Island shows there were two periods of severe cold, at c. 30,000 BP and c. 21,700 BP, and that the entire period c. 33,000 to 18,000 BP was 'punctuated by abrupt periods of increasing aridity' (Petherick et al. 2008:800; see also Petherick et al. 2009). During the LGM, and in the period leading up to it, it would seem that much of the coastal strip of eastern Australia was a distinctly rebarbative environment - cold, dry, sparsely vegetated and subject to widespread dust storms.

\section{Conclusions}

It might be concluded, therefore, that the eastern Australian coastal strip during the Pleistocene was not a haven for human occupation, certainly not in the period 30,000-18,000 BP. It is, of course, possible that it was occupied before that, in the period now generally accepted as the timeframe for the human colonisation of Australia, 60,000-40,000 BP. It is further possible that that occupation was too sparse to leave any archaeological traces. On the other hand, perhaps we can suggest that the coastal colonisation of Australia (cf. Bowdler 1977) did not, in fact, embrace the east coast, which a small exploring population found distinctly unattractive and unnecessary. We know that people were on the western side of the Great Dividing Range by 40,000 years ago, and began to penetrate the western slopes of the eastern highlands not long after. Perhaps after the retreat of the glaciers, the east coast began to look like a more attractive proposition, luring travellers from the west to filter down its precipitous eastern cliffs and gullies to explore the newly emerging well-watered, resource-rich coasts and rivers of an eastern Eden.

\section{Acknowledgements}

Thanks to the Thylacine Club and ace member Geoff Hope all those years ago. Thanks also to Jane Balme for running an eagle eye over this, but of course she is not responsible for the contentious bits.

\section{References}

Allen, J. (ed) 1996. Report of the southern forests archaeological project. Volume 1. Site descriptions, stratigraphies and chronologies. Bundoora: School of Archaeology, La Trobe University.

Allen, J. and N. Porch 1996. Warragarra rockshelter. In J. Allen (ed) Report of the southern forests archaeological project. Volume 1. Site descriptions, stratigraphies and chronologies, pp195-217. Bundoora: School of Archaeology, La Trobe University.

Attenbrow, V. 2004. What's changing: population size or land-use patterns? The archaeology of the Upper Mangrove Creek, Sydney Basin. Terra Australia 21. Canberra: Pandanus Books. 
Barker, B. 2004. The Sea People: Late Holocene maritime specialisation in the Whitsunday Islands, central Queensland. Terra Australis 20. Canberra: Pandanus Books.

Beaton, J.M. 1985. Evidence for a coastal occupation time-lag at Princess Charlotte Bay (North Queensland) and implications for coastal colonisation and population growth theories for Aboriginal Australia. Archaeology in Oceania 20:1-20.

Boot, P. 1993. Pleistocene date from archaeological excavations in the hinterlands of the New South Wales south coast. Australian Archaeology 37:59.

Boot, P. 1994. Recent research into the prehistory of the hinterland of the south coast of New South Wales. In M. Sullivan, S. Brockwell and A. Webb (eds) Archaeology in the North: Proceedings of the 1993 Australian Archaeological Association Conference, pp319-340. Darwin: North Australia Research Unit (ANU).

Border, A. 1999. Aboriginal settlement of offshore islands in the Southern Great Barrier Reef Province, central Queensland. In J. Hall and I. J. McNiven (eds) Australian Coastal Economies, pp129-139. Canberra: ANH Publications, Department of Archaeology and Natural History, RSPAS, ANU.

Bowdler, S. 1970. Bass Point: the excavation of a southeast Australia shell midden showing cultural and economic change. Unpublished BA (Hons) thesis, Sydney, University of Sydney.

Bowdler, S. 1976. Hook, line and dillybag: an interpretation of an Australian coastal shell midden. Mankind 10:248-258.

Bowdler, S. 1977. The coastal colonisation of Australia. In J. Allen, J. Golson and R. Jones (eds) Sunda and Sahul: Prehistoric Studies in Southeast Asia, Melanesia and Australia, pp205246. London: Academic Press.

Bowdler, S. 1981. Hunters in the highlands: Aboriginal adaptations in the eastern Australian uplands. Archaeology in Oceania 16:99-111.

Bowdler, S. 1984. Hunter Hill, Hunter Island Terra Australis 8. Canberra: Dept. of Prehistory, Research School of Pacific Studies, Australian National University.

Bowdler, S. 1999. Research at Shark Bay, WA, and the nature of coastal adaptations in Australia. In J. Hall and I. J. McNiven (eds) Australian Coastal Economies, pp79-84. Canberra: ANH Publications, Department of Archaeology and Natural History, RSPAS, ANU.

Bowler, J.M., H. Johnston, J.M. Olley, J.R. Prescott, R.G. Roberts, W. Shawcross and N.A. Spooner 2003. New ages for human occupation and climatic change at Lake Mungo, Australia. Nature 421: 837-840.

Callaghan, M. 1980. Some previously unconsidered environmental factors of relevance to south coast prehistory. Australian Archaeology 11:43-49.

Cane, S. 2001. The Great Flood: eustatic change and cultural change in Australia during the Late Pleistocene and Holocene. In A. Anderson, I. Lilley and S. O'Connor (eds) Histories of Old Ages: essays in honour of Rhys Jones, pp141-165. Canberra: Pandanus Books.

Coutts, P.J.F. 1967. Coastal dunes and field archaeology in S. E. Australia. Archaeology and Physical Anthropology in Oceania 2:28-34.

David, B., R. Roberts, C. Tuniz, R. Jones and J. Head 1997. New optical and radiocarbon dates from Ngarrabullgan Cave, a Pleistocene archaeological site in Australia: implications for the comparability of time clocks and for the human colonization of Australia. Antiquity 71:183-188.

David, B., R.G. Roberts, J. Magee, J. Mialanes, C. Turney, M. Bird, C. White, K. Fifield and J. Tibby 2007. Sediment mixing at Nonda Rock: investigations of stratigraphic integrity at an early archaeological site in northern Australia and implications for the human colonisation of the continent. Journal of Quaternary Science 22:449-479.

Dodson, J.R. and B.G. Thom 1992. Holocene vegetation history from the Hawkesbury Valley, New South Wales. Proceedings of the Linnean Society of New South Wales 113:121-134. 
Dunnett, G. 1993. Diving for dinner: some implications from Holocene middens for the role of coasts in the late Pleistocene of Tasmania. In M. A. Smith, M. Spriggs and B. Fankhauser (eds) Sahul in Review: Pleistocene Archaeology in Australia, New Guinea and Island Melanesia, pp247-257. Occasional Papers in Prehistory No. 24. Canberra: Department of Prehistory, Research School of Pacific Studies.

Dyall, L.K. 1982. Aboriginal fishing stations on the Newcastle coastline, New South Wales. In S. Bowdler (ed) Coastal Archaeology in Eastern Australia, pp52-62. Canberra: Department of Prehistory, Research School of Pacific Studies, Australian National University.

Flood, J., B. David, J. Magee and B. English 1987. Birrigai: a Pleistocene site in the southeastern highlands. Archaeology in Oceania 22:9-26.

Gillespie, R. and R.B. Temple 1977. Radiocarbon dating of shell middens. Archaeology and Physical Anthropology in Oceania 12:26-37.

Hesse, P.P., G.S. Humphreys, P.M. Selkirk, D.A. Adamson, D.B. Gore, D.C. Nobes, D.M. Price, J. -L. Schwenninger, B. Smith, M. Tulau and F. Hemmings 2004. Late Quaternary aeolian dunes on the presently humid Blue Mountains, eastern Australia. Quaternary International 108:13-32.

Hope, G.S. 1978. The late Pleistocene and Holocene vegetational history of Hunter Island, north-western Tasmania. Australian Journal of Botany 24:493-514.

Hughes, P.J. 1981. The impact of bushfires on soils and soil erosion. In P. Stanbury (ed) Bushfires: Their Effect on Australian Life and Landscape, pp33-37. Sydney: The Macleay Museum, University of Sydney.

Jones, R. 1968. The geographical background to the arrival of man in Australia and Tasmania. Archaeology and Physical Anthropology in Oceania 3:186-215.

Jones, R. 1995. Tasmanian archaeology: establishing the sequences. Annual Review of Anthropology 24:423-446.

Kershaw, A.P. 1995. Environmental change in Greater Australia. Antiquity 69:656-675.

Lampert, R.J. 1971. Burrill Lake and Currarong. Terra Australis 1. Canberra: Department of Prehistory, Research School of Pacific Studies, Australian National University.

Lampert, R.J. and P.J. Hughes 1974. Sea level change and Aboriginal coastal adaptations in southern New South Wales. Archaeology and Physical Anthropology in Oceania 9:226-235.

Lees, B. 2006. Timing and formation of coastal dunes in northern and eastern Australia. Journal of Coastal Research 22:78-79.

McDonald, J. 2008. Dreamtime Superhighway: Sydney Basin Rock Artand Prehistoric Information Exchange. Terra Australia 27. Canberra: Pandanus Books, Australian National University.

McGowan, H.A., L.M. Petherick and B.S. Kamber 2008. Aeolian sedimentation and climate variability during the late Quaternary in southeast Queensland, Australia. Palaeogeography, Palaeoclimatology, Palaeoecology 265:171-181

Megaw, J.V.S. 1968. A dated cultural sequence for the south Sydney region of New South Wales. Current Anthropology 9:325-329.

Morse, K. 1999. Coastwatch: Pleistocene resource use on the Cape Range Peninsula. In J. Hall and I. McNiven (eds) Australian Coastal Archaeology, pp73-78. Canberra: ANH Publications, R.S.P.A.S., Australian National University.

Mulvaney, D.J. and E.B. Joyce 1965. Archaeological and geomorphological investigations on Mt Moffatt Station, Queensland, Australia. Proceedings of the Prehistoric Society $31: 147-212$.

Neal, R. and E. Stock 1986. Pleistocene occupation in the south-east Queensland region. Nature 323:618-621.

Petherick, L.M., H.A. McGowan and B.S. Kamber 2009. Reconstructing transport pathways for late Quaternary dust from eastern Australia using the composition of trace elements of long traveled dusts. Geomorphology 105:67-79. 
Petherick, L., H. McGowan and P. Moss 2008. Climate variability during the Last Glacial Maximum in eastern Australia: evidence of two stadials? Journal of Quaternary Science 23:787-802.

O'Connor, S. 1999. 30,000 years of Aboriginal occupation: Kimberley, north west Australia. Terra Australis 14. Canberra: ANH Publications and the Centre for Archaeological Research, Australian National University.

Pike-Tay, A., R. Cosgrove and J. Garvey 2008. Systematic seasonal land use by late Pleistocene Tasmanian Aborigines. Journal of Archaeological Science 35:2532-2544.

Rowland, M.J. 1996. Prehistoric archaeology of the Great Barrier Reef province - retrospect and prospect. In P. Veth and P. Hiscock (eds) Archaeology of Northern Australia: Regional Perspectives, pp190-212. Tempus 4. St Lucia: Anthropology Museum, University of Queensland.

Sim, R. 1994. Prehistoric human occupation in the King and Furneaux Island regions, Bass Strait. In M. Sullivan, S. Brockwell and A. Webb (eds) Archaeology in the North: Proceedings of the 1993 Australian Archaeological Association Conference, pp358-374. Darwin: North Australia Research Unit (ANU).

Stockton, E.D. 1993. Archaeology of the Blue Mountains. In Eugene Stockton (ed) Blue Mountains Dreaming the Aboriginal Heritage, pp23-52. Winmalee (NSW): Three Sisters.

Ulm, S., B. Barker, A. Border, J. Hall, I. Lilley, I. McNiven, R. Neal and M. Rowland 1995 Pre-European coastal settlement and use of the sea: a view from Queensland. Australian Archaeology 41:24-26. 